\title{
DETERMINANTS OF CREDIT ACCESS OF COCOA FARMERS
}

\author{
${ }^{1}$ Nicholas Oppong Mensah, ${ }^{2}$ Edward Yeboah, ${ }^{3}$ Anthony Donkor, \\ ${ }^{4}$ Frank Osei Tutu, ${ }^{5}$ Richard Kaanye Dier
}

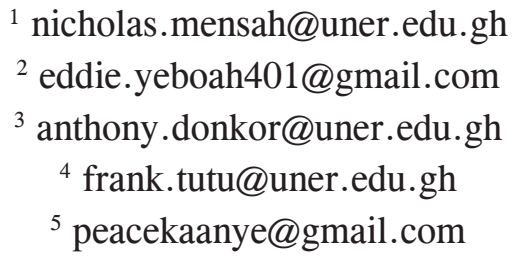

${ }^{1}$ School of Agriculture and Technology, Department of Agricultural Economics, Agribusiness, and Extension, University of Energy and Natural Resources (UENR), Sunyani, Ghana.

${ }^{2}$ Department of Accounting and Finance, KNUST School of Business, Kwame Nkrumah University of Science and Technology (KNUST), Kumasi, Ghana.

${ }^{3}$ School of Agriculture and Technology, Department of Agricultural Economics, Agribusiness, and Extension, University of Energy and Natural Resources (UENR), Sunyani, Ghana.

${ }^{4}$ School of Agriculture and Technology, Department of Agricultural Economics, Agribusiness, and Extension, University of Energy and Natural Resources (UENR), Sunyani, Ghana.

${ }^{5}$ School of Agriculture and Technology, Department of Agricultural Economics, Agribusiness, and Extension, University of Energy and Natural Resources (UENR), Sunyani, Ghana.

\begin{abstract}
Access to credit is one of the critical areas that are of prime interest to development practitioners, agribusiness entrepreneurs and agricultural economists, mainly access to credit by farmers in order to increase their production and also reduce poverty. This study sought to analyze the determinants of credit access among cocoa farmers in the Asunafo North of the Ahafo Region of Ghana. The multistage sampling procedure was used to collect data from 100 cocoa farmers with the aid of a questionnaire. Sources of credit, factors influencing access to credit, and constraints to credit were analyzed with the aid of descriptive statistics, multiple linear regression, and Kendall's coefficient of concordance respectively. The results of multiple linear regression revealed that, age, marital status, education, experience, and family size were significant factors that influenced access to credit. The constraints analysis with the aid of Kendall's coefficient of concordance showed that, high interest rate was highly ranked with a mean score of 1.93 whilst the need for a guarantor was least ranked with a mean score of 7.40. Based on the results, the study recommended that a policy aimed at expanding formal and semi-formal financial institutions credit portfolio to embrace cocoa farmers by finding alternative to collaterals and also reducing the interest rate will improve credit access with a positive externality effect of poverty reduction among cocoa farmers in the study area.
\end{abstract}

Keywords: access to credit; sources of credit; constraints to credit; and interest rate (JEL Classification: Q14) 


\section{INTRODUCTION}

Cocoa has been observed to be an essential cash crop in Ghana. The cocoa industry comes with exclusive characteristics involve small-scale farmers production of the beans; Licensed companies specialized in purchasing cocoa beans and development of warehouse for storing the beans, while Ghana Cocoa Board ensures the quality of the beans (Obuobisa, 2015). Ensuring that farmers have access to credit (Financial inclusion) will increase their tendency to expand their cocoa production, buy modernized equipment or tools to improve their production and consequently save in the long run to meet future needs that could be expensive.

Various factors have been identified as affecting access to credit by farmers. Amongst others are gender (Nyemeck, Gockowski, and Nkamleu 2008); age (Abdul, 2015); education (Abdul, 2015; Essien and Arene, 2014); marital status (Okunade, 2007); household size (Essien and Arene 2014; Chandio, Jiang, Rehman, and Liu 2017); experience in farming (Nouman, Siddiqi, Asim, and Hussain 2013); and awareness (Chenaa, Maria, and Teno, 2018). This study seeks to underscore the implications of these factors on accessibility to credit by cocoa farmers at the Asunafo North Municipality in the Ahafo Region of Ghana.

\section{MATERIALS AND METHODS}

\section{Research Design}

Descriptive and explanatory research designs were adopted. Descriptive statistics were used to describe the socio-economic characteristics of cocoa farmers, while multiple regression was applied to determine the factors that influence access to credit by cocoa farmers in the study location.

\section{Population}

The target population for the study was highly dependent on cocoa farmers in the Asunafo North Municipality in the Ahafo Region of Ghana. The population size for cocoa farmers in the study location was approximately 45,000.

\section{Sample size}

With the utilization of the formulae by (Israel, 1992) for the determination of sample size, 100 cocoa farmers were selected. The formula was given as:

$$
n=\frac{N}{1+N e}
$$

Where $\mathrm{n}=$ Size of the sample, $\mathrm{N}=$ Size of population, and $\mathrm{e}=$ Precision level

With the approximated cocoa farmers population of 45,000 at a precision level of $10 \%$, the sample size was determined as:

$$
n=\frac{45,000}{1+45,000(0.1)^{2}}=99.77 \approx 100 \ldots \ldots .[2]
$$

\section{Sampling Procedure}

The multistage sampling procedure was used to select the 100 farmers. The first stage involving the selection of three (3) communities. These communities were Mim, Gyaenkontabuo, and Asuadae. The second stage involved the number of farmers to be interviewed in each community; therefore forty-nine (49), twenty-eight (28), and twenty-three (23) farmers were interviewed in Mim, Gyaenkontabuo, and Asuadae respectively making the total number of respondents who are cocoa farmers (100).

\section{Data Collection}

The study relied extensively on primary data. The primary data was obtained via the administration of a structured questionnaire in the form of interviews to engender a response from farmers.

\section{Data Analysis}

Multiple linear regression was used to determine the factors influencing access to credit. The regression model was specified as:

$$
\begin{aligned}
& \mathrm{Y}=\beta_{\mathrm{O}}+\beta_{1} \mathrm{X}_{1}+\beta_{2} \mathrm{X}_{2}+\beta_{3} \mathrm{X}_{3}+\beta_{4} \mathrm{X}_{4}+\beta_{5} \mathrm{X}_{5}+\beta_{6} \mathrm{X}_{6}+ \\
& \beta_{7} \mathrm{X}_{7}+\varepsilon \ldots \ldots \ldots \ldots \ldots \ldots \ldots \ldots \ldots \ldots \ldots \ldots \ldots \ldots \ldots \ldots \ldots \ldots \ldots
\end{aligned}
$$

\begin{tabular}{|c|c|c|c|c|}
\hline Variable & $\begin{array}{c}\text { Variable } \\
\text { Definition }\end{array}$ & $\begin{array}{l}\text { Type of } \\
\text { Variable }\end{array}$ & $\begin{array}{c}\text { Description of } \\
\text { Variables }\end{array}$ & $\begin{array}{c}\text { A-priori } \\
\text { Expectation }\end{array}$ \\
\hline $\mathrm{X}_{1}$ & Gender & $\begin{array}{l}\text { Dummy } \\
1=\text { Male } \\
0=\text { Female }\end{array}$ & Sex of farmer & $+/-$ \\
\hline $\mathrm{X}_{2}$ & Age & Continuous & $\begin{array}{c}\text { Farmers age in } \\
\text { years }\end{array}$ & $+/-$ \\
\hline $\mathrm{X}_{3}$ & $\begin{array}{c}\text { Educational } \\
\text { level }\end{array}$ & $\begin{array}{c}\text { Years } \\
\text { (Continuous) }\end{array}$ & $\begin{array}{c}\text { Educational } \\
\text { Level of farmer }\end{array}$ & + \\
\hline $\mathrm{X}_{4}$ & Family size & $\begin{array}{l}\text { Discrete } \\
\text { Variable }\end{array}$ & $\begin{array}{l}\text { Number of } \\
\text { people }\end{array}$ & $+/-$ \\
\hline $\mathrm{X}_{5}$ & $\begin{array}{c}\text { Farm } \\
\text { experience }\end{array}$ & $\begin{array}{c}\text { Years } \\
\text { (Continuous) }\end{array}$ & $\begin{array}{l}\text { Farmer's years } \\
\text { of experience in } \\
\text { farming }\end{array}$ & + \\
\hline $\mathrm{X}_{6}$ & Marital status & $\begin{array}{l}\text { Discrete } \\
\text { variable }\end{array}$ & $\begin{array}{c}\text { Marital status of } \\
\text { farmer }\end{array}$ & $+/-$ \\
\hline $\mathrm{X}_{7}$ & Awareness & Categorical & $\begin{array}{c}\text { Awareness of } \\
\text { credit }\end{array}$ & + \\
\hline Y & $\begin{array}{l}\text { Dependent } \\
\text { variable }\end{array}$ & & Access to credit & \\
\hline Bo & & & Constant & \\
\hline$\beta \mathrm{i}$ & & & $\begin{array}{l}\text { Independent } \\
\text { Variable } \\
\text { Coefficients }\end{array}$ & \\
\hline $\mathrm{E}$ & & & $\begin{array}{l}\text { Stochastic } \\
\text { error term }\end{array}$ & \\
\hline
\end{tabular}

The description of the variables of the multiple linear regression is shown in Table 1 below.

Table 1: Description of variables

Source: Authors' Construct, 2019 


\section{Study location and size}

Asunafo North Municipality is one of the six (6) Districts in the Ahafo Region of Ghana. In the year 2004, the Municipality was created as a result of the division of the Asunafo District. In the North-East, the Municipality shares border with Asutifi District, North-West Dormaa Municipality, South-West Juaboso-Bia and Sefwi-Wiawso; and for South-Eastern it shares boundaries with Asunafo South District. The Municipality has a land size of 1,412.0 $\mathrm{km} 2$ with an area of $578.63 \mathrm{~km} 2$ covered by forest (Okity, 2016). Figure 1 shows a map of the study area.

Figure 1: Asunafo North Municipality Map.

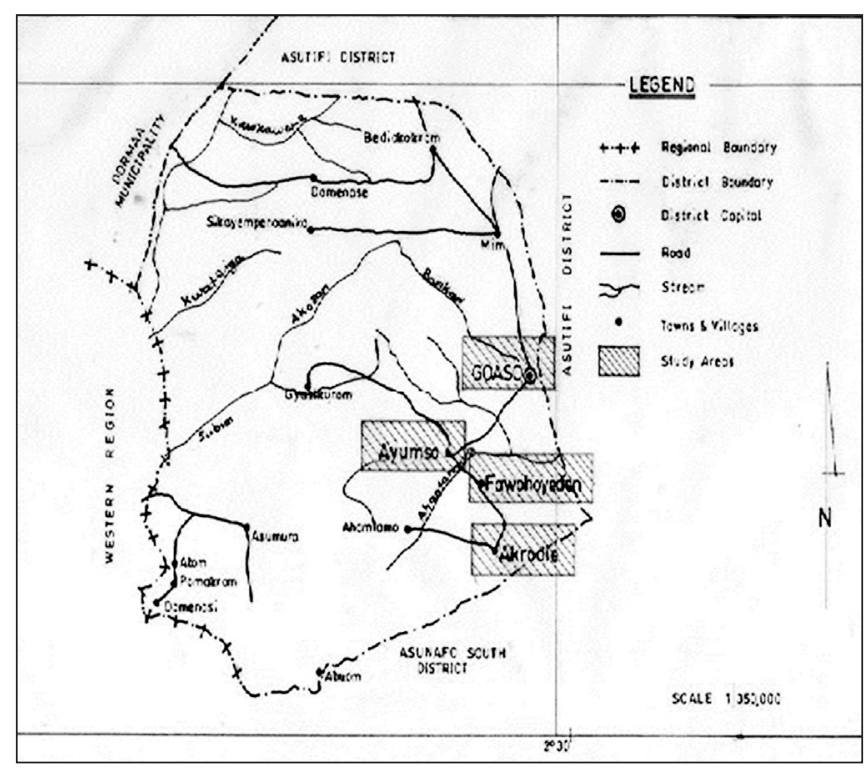

Source: (Okity, 2016).

\section{RESULTS AND DISCUSSIONS}

\section{Socio-Economic Characteristics}

The socio-economic characteristics of respondents are shown in Table 2 below.

From Table 2, age is significant in determining the productivity of the labour force of farmers. The results from Table 2 above indicated that $47 \%$ of the cocoa farmers were within the age range of 31-45 years, 35\% of the farmers were within the age range of 46-59 years whilst only $8 \%$ of the farmers were 60 years and above. This shows that respondents were mostly in their middle ages which implied that cocoa farmers were still in their economic active age which will have a positive effect on production if the right technologies and agronomic practices are not adopted.

The distribution in Table 2 above shows that the majority of the respondents were predominately males represented by $62 \%$ of whilst females accounted for $38 \%$. This shows that farming or cocoa production in the study area is gendered in favour of males. However, the population of female participation in these production activities is encouraging.
Females can also take up cocoa farming as their primary occupation in order to be empowered financially. Moreover, the results also showed that, women are more involved in post-harvest handling such as drying and fermentation in the cocoa value activities which attracted fewer rewards. Perhaps the females used the rest of their time to engage in domestic and reproductive activities, while males are more dedicated to productive activities.

Table 2: Socio-economic characteristics

\begin{tabular}{|c|c|c|}
\hline Variable & $\begin{array}{l}\text { Frequency } \\
\text { (N) }\end{array}$ & $\begin{array}{l}\text { Percentage } \\
\quad(\%)\end{array}$ \\
\hline \multicolumn{3}{|l|}{ Gender: } \\
\hline Male & 62 & 62.0 \\
\hline Female & 38 & 38.0 \\
\hline \multicolumn{3}{|l|}{ Age: } \\
\hline $18-30$ & 10 & 10.0 \\
\hline $31-45$ & 47 & 47.0 \\
\hline $46-59$ & 35 & 35.0 \\
\hline 60 and above & 8 & 8.0 \\
\hline \multicolumn{3}{|l|}{ Marital status: } \\
\hline Single & 12 & 12.0 \\
\hline Married & 86 & 86.0 \\
\hline Divorced & 2 & 2.0 \\
\hline \multicolumn{3}{|l|}{ Religion: } \\
\hline Christian & 70 & 70.0 \\
\hline Islam & 28 & 28.0 \\
\hline Others & 2 & 2.0 \\
\hline \multicolumn{3}{|c|}{ Educational status: } \\
\hline Non formal & 24 & 24.0 \\
\hline Primary & 13 & 13.0 \\
\hline MSLC/JHS & 34 & 34.0 \\
\hline Technical/SHS & 21 & 21.0 \\
\hline Vocational & 3 & 3.0 \\
\hline Tertiary & 5 & 5.0 \\
\hline \multicolumn{3}{|l|}{ Family size: } \\
\hline None & 7 & 7.0 \\
\hline $1-3$ & 10 & 10.0 \\
\hline $4-6$ & 49 & 49.0 \\
\hline 7 or more & 34 & 34.0 \\
\hline \multicolumn{3}{|l|}{ Experience: } \\
\hline $1-5$ & 3 & 3.0 \\
\hline 6-10 & 12 & 12.0 \\
\hline $11-15$ & 18 & 18.0 \\
\hline $16-20$ & 40 & 40.0 \\
\hline
\end{tabular}

Source: Field Data, 2019

The majority $(86 \%)$ of the respondents as indicated in Table 2 above, were married, whilst $12 \%$ were single and only $2 \%$ were divorced. This indicated that the majority of the farmers in the study area were matured and had emotional support from their spouses in decision making and farming 
activities which is very important to them. Furthermore, most (70\%) of the respondents were Christians, 28\% Islam, and $2 \%$ had other forms of religion that influence their production decision.

Education connotes capabilities and capacity to engage in management and productive activities and decision making in a higher form which influences access to credit. Concerning education, about $76 \%$ of the respondents as shown in Table 2 above, had formal education whilst only $24 \%$ of the respondents had no formal education. This indicates that the majority of the farmers attended school from primary, MSLC/JHS to SHS, which proves that the respondents are fairly educated. Hence their access to credit in the formal institution will be curtailed.

However, $49 \%$ of the respondents, as depicted in Table 2 above, had a family size range of $4-6$, whilst $37 \%$ of the respondents had a family size of 7 or more. Only $7 \%$ of the farmers had a family size range of 1 to 3 . This illustrates that the family size of cocoa farmers is relatively large; this is because in most farming communities, farmers rely on family labour for most of their farming activities. This helps them to cut down labour cost, increase their household expenditure, which may influence their decision to go for credit.

The majority (40\%) of the farmers as shown in Table 2 above, had years of cocoa farming experience which ranges between 16 to 20 years. The relatively high number of experienced cocoa farmers suggests that cocoa production is a lifelong occupation that requires continuous practice that later translates into experience, which may influence their access to credits since the default rate will be low when a farmer is experienced.

Nonetheless, 92\% of the respondents as indicated in Figure 2 below had access to credit whilst $8 \%$ had no form of credit access. This also corroborates the findings of (Dabone, Osei and Petershie 2014) who noted that most of the farmers (58\%) had access to credit whilst $41.5 \%$ did not have access to credit.

Figure 2: Access to credit

No__ Yes $\because$ No Yes

Source: Field Data, 2019

With regards to sources of credit, the majority of the farmers (39\%) had a loan from their family and neighbours, $35 \%$ secured loans from money lenders, whilst the minority obtained loans from co-operatives (26\%) as shown in Figure 3. Contrary to the results (Ijioma and Osondu 2015) reported that $30 \%$ of the respondents sourced their credit from friends, $14.44 \%$ from money lenders, $43.33 \%$ from corporative societies, and $12.22 \%$ from formal sources. These sources indicated that the farmers have access to credit from largely informal sources and one semiformal source. This is a wake-up call for semiformal and formal financial institutions in the study area.

Figure 3: Source of credit Source: Field Data, 2019

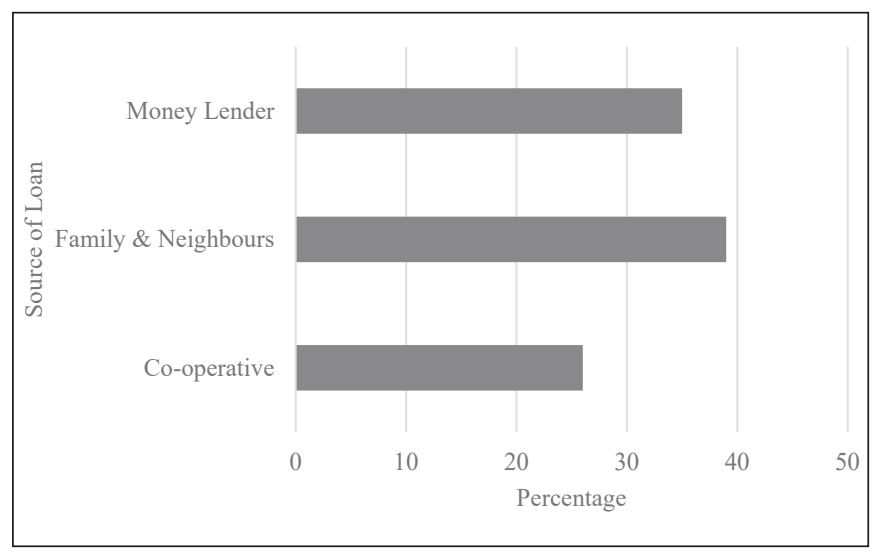

Factors influencing access to credit

Table 3: Determinants influencing credit access

\begin{tabular}{|c|c|c|c|c|}
\hline Variables & Coefficient & $\begin{array}{l}\text { Standard } \\
\text { Error }\end{array}$ & T-Value & $\begin{array}{c}\text { Significance } \\
\text { level }\end{array}$ \\
\hline Constant & -20679.958 & 7172.020 & -2.883 & $0.005^{* * *}$ \\
\hline Gender & 2032.836 & 1615.455 & 1.258 & 0.211 \\
\hline Age & 3303.181 & 1082.844 & 3.050 & $0.003 * * *$ \\
\hline $\begin{array}{l}\text { Marital } \\
\text { Status }\end{array}$ & -6131.478 & 1726.823 & -3.551 & $0.001 * * *$ \\
\hline Education & 2055.377 & 519.832 & 3.954 & $0.000 * * *$ \\
\hline Experience & -574.783 & 327.221 & -1.757 & $0.082 * *$ \\
\hline Awareness & 5267.629 & 3986.194 & 1.321 & 0.190 \\
\hline Family Size & 2355.151 & 256.650 & 9.177 & $0.000 * * *$ \\
\hline $\mathrm{R}^{2}$ & $=0.659$ & - & - & - \\
\hline F-Value & $=25.379$ & - & - & - \\
\hline $\begin{array}{l}\text { Durbin- } \\
\text { Watson }\end{array}$ & $=1.653$ & - & - & - \\
\hline
\end{tabular}

Source: Field Data, 2019

***1\% Significance Level, **10\% Significance Level 
Table 3 shows the R-squared for factors influencing access to credit. The explanatory variables jointly explained 0.659 or $66 \%$ of the variations that occurred in the dependent variable (access to credit). This implies that the model can also explain 34\% of some factors. DurbinWatson value of 1.653 shows clearly that, the predicted factors had no autocorrelation.

The results from the model indicated that gender had a positive coefficient but was not statistically significant; this corresponded with the a-priori expectation. The result is consistent with the study of (Nyemeck et al. 2008). He reported that gender was not statistically significant; therefore, this factor did not influence farmers' ability to access credit.

Age was positive and significant at a significance level of $1 \%$. This implies that an increase in farmers' age increases the farmer's ability to access credit. The result is in line with the findings of Abdul (2015), who analyzed the factors influencing access to credit and how it affects food security. The findings of his study revealed that an increase in age increases the credit amount acquired by a farmer.

Marital status had a negative coefficient but was statistically significant at a $1 \%$ significance level. This implies that married farmers are less likely to get access to credit. The result was consistent with the a-priori expectation. The result corroborates the findings of (Okunade, 2007). His findings revealed that marital status was insignificant.

Furthermore, the coefficient of education was positive and significant at a significance level of $1 \%$. This shows that, farmers who have attained education have higher chances of securing credit in comparison to farmers who had no formal education. The result was consistent with the findings of (Abdul, 2015), and (Essien and Arene 2014). They reported that education and access to credit were positively related lines with a-priori expectation.

Experience had a negative coefficient but was statistically significant at a $10 \%$ significance level. The results show that experience was contrary to a-priori expectation. This implies that the more one experiences in farming decreases one access to credit contrary to the study of (Nouman et al. 2013). Whose study revealed that, farming experience was positive but insignificant.

Awareness was positive but insignificant, implying that it had no association in accessing credit. However, it was consistent with a-priori expectation. The result was in line with the findings of (Chenaa et al. 2018) who observed that awareness was positive, with a coefficient of 8.908.

The coefficient of family size was positive and significant at a $1 \%$ significance level. Also, it was consistent with a-priori expectation. This implies that an increase in family size increases one's likelihood of seeking credit. Therefore, the higher the number of people in a family, the higher the demand for credit. The results were consistent with the study of (Chandio et al. 2017). The findings of their study show that household size was positive and significant.

\section{Constraints to credit access}

Table 4: Constraints in accessing credit

\begin{tabular}{|l|l|l|}
\hline Constraints & Mean Rank & Rank \\
\hline High interest rate & 1.93 & 1 \\
\hline Provision of collateral & 3.20 & 2 \\
\hline Cumbersome process & 3.47 & 3 \\
\hline Distance to credit facility & 4.10 & 4 \\
\hline Lack of education & 5.29 & 5 \\
\hline Gender biases & 5.88 & 6 \\
\hline Diversion of loan & 6.59 & 7 \\
\hline Short payback period & 7.33 & 8 \\
\hline Need a guarantor & 7.40 & 9 \\
\hline N & 100 & \\
\hline Kendall's W & 0.531 & \\
\hline Chi-square (X2) & 424.875 & \\
\hline Degree of freedom (df) & 8 & \\
\hline Asymptotic Significance & 0.000 & \\
\hline
\end{tabular}

Source: Field Data, 2019

Table 4 presents the constraints in acquiring credit. The high rate of interest was the highest constraint to credit acquisition. Furthermore, the provision of collateral, and cumbersome process were observed as the second and third constraints in accessing credit. Distance to the credit facility, lack of education, and gender biases had 4th, 5th, and 6th rank respectively whilst diversion of loan, short payback period, and the need for a guarantor was observed as the least constraints in accessing credit.

Kendall's W of 0.531 shows that $53 \%$ of the farmers were in agreement with the ranked constraints. The null hypothesis was rejected in favour of the alternative. Therefore, there was an agreement in the ranked constraints. Farmers diverted loans because they had to pay for their children's school fees and sometimes pay for their health bills.

\section{CONCLUSION AND RECOMMENDATIONS}

Age, marital status, education, experience, and family size were factors that influenced the farmer's ability to access credit in the study location. It is recommended that: 1 . Credit with education as delivery models in credit extension to farmers by financial institutions and players in credit administration be invigorated. This will not only elevate the skills of farmers in credit management but also improve loan repayments thereby sustaining cordial relationship of farmers with financial institutions. 
2. Polices aimed that at expanding formal and semi-formal financial institutions credit portfolio to embrace cocoa farmers sought increasingly be sought.

3. Affordable interest rate regime for cocoa farmers should be the priority of government.

4. Workable collateral and guarantee systems on credit for cocoa farmers should the agenda of players in the financial service industry.

\section{REFERENCES}

Abdul-Jalil MA. (2015): Determinants of access to credit and its impact on household food security in Karaga District of the Northern Region of Ghana (Doctoral dissertation).

Chandio AA, Jiang Y, Wei F, Rehman A, Liu D. (2017): Famers' access to credit: Does collateral matter or cash flow matter? Evidence from Sindh, Pakistan. Cogent Economics \& Finance, 2017; 5(1), 1369383.

Chenaa TA., Maria AG, Teno MN. (2018): Determinants of Access to Credit and Performance of Smallholder Farmers in Kumba Municipality, South West Region of Cameroon. Asian Journal of Agricultural Extension, Economics \& Sociology, 2018; 1-12.

Dabone AJ, Osei BA, Petershie BE. (2014): The Determinants of Access to Credit for Cash Crop Production in Ghana: A Case Study of the Cocoa Industry. Developing Country Studies, 2014; 4(14), 63-72.

Essien UA, Arene CJ. (2014): An analysis of access to credit markets and the performance of small scale agro-based enterprises in the Niger Delta region of Nigeria. International Journal of Food and Agricultural Economics (IJFAEC), 2014; 2 (1128-2016-92048), 105.

Ijioma JC, Osondu CK. (2015): Agricultural credit sources and determinants of credit acquisition by farmers in Idemili Local Government Area of Anambra State. Journal of Agricultural Science and Technology B, 2015; 5(1), 34-43.

Israel GD. (1992): Determining Sample Size, Agricultural Education and Communication Department, University of Florida, IFAS Extension, PEOD6 (Reviewed 2013)

Nouman M, Siddiqi M, Asim S, Hussain Z. (2013): Impact of socio-economic characteristics of farmers on access to agricultural credit. Sarhad Journal of Agriculture, 2013; 29(3), 469-476.

Nyemeck JB, Gockowski J, Nkamleu GB. (2008): The role of credit access in improving cocoa production in West African countries, 2008; (No. 307-2016-4928, p. 105).

Obuobisa-Darko E. (2015): Credit access and adoption of cocoa research innovations in Ghana. Res. Humanit. Soc. Sci, 2015; 5 , 16-29.

Okity-Boamah D. (2016): Effects of intermediate centres on rural development in Ghana: a comparative study of Obuasi and Asunafo North Municipalities (Doctoral dissertation).

Okunade E. (2007): Accessibility of agricultural credit and inputs to women farmers of Isoya Rural Development Project. Research Journal of Agriculture and Biological Services, 2007; 3(3), 138-142. 